\title{
Economic Growth, Inflation, and Regional Minimum Wage: An Empirical Investigation of the Open Unemployment Rate in Sumatera, Indonesia
}

\author{
Rian Putra ${ }^{1}$ Ketut Sukiyono ${ }^{2}$ Purmini $^{3}$ \\ 1,3 Magister Program of Applied Economics, Faculty of Economics and Business \\ University of Bengkulu \\ 2 Department of Agricultural Socio-Economics, Faculty of Agriculture, University of \\ Bengkulu \\ Email : ksukiyono@unib.ac.id
}

How to Cite :

Putra, R., Sukiyono, K., Purmini. 2021. Economic Growth, Inflation, and Regional Minimum Wage: An Empirical Investigation of the Open Unemployment Rate in Sumatera, Indonesia. Journal of Agri Socio Economics and Business. 03 (2): 109-122. DOI: https://doi.org/10.31186/jaseb.03.2.109-122

\section{ARTICLE HISTORY}

Received [15 Sept 2021]

Revised [01 Nov 2021]

Accepted [21 Dec 2021]

\section{KEYWORDS}

Economics growth, inflation, regional minimum wage, open unemployment.

This is an open access article under the $\underline{C C-B Y-S A}$ license

\section{ABSTRACT}

The purpose of this study is to investigate the determinants of the open unemployment rate in Sumatera island Indonesia. We conjecture that the variation of the open unemployment rate (OUR) is the function of economic growth (EG), inflation (INF), and regional minimum wage $(R M W)$. Using the sample of ten provinces in Sumatera island from 2006 to 2018, we further perform a panel data analysis with a random effect model (REM). The obtained empirical results show that there is a negative association between the independent variables (i.e., EG, RMW) and the dependent variable (OUR), while INF does not show any significant association with OUR. Referring to the empirical evidence, we infer that economic growth and regional minimum wage play an essential role in explaining the variation of the open unemployment rate in Sumatera island..

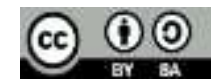




\section{INTRODUCTION}

Inspired by the previous macroeconomics studies, our study aims to examine the effect of economic growth (EG), inflation (INF), and regional minimum wage (RMW) on the variations in the open unemployment rate (OUR). The works of literature have well-documented that the relationship between macroeconomic variables should show a linear relationship, where the implementation of a policy is expected to be in line with expectations of the output desired by the government as policymakers and decisionmakers (Phillips, 1958; Sukirno, 2010). In this context, there have been several empirical studies that have examined the relationship between macroeconomic variables (e.g., economic growth, inflation, regional minimum wages, and open unemployment rate). However, the results shown by previous literature are more concentrated in studies with the settings in Java island, and very few research studies have been disseminated with different sets of studies other than Java island case

According to the data published by the Central Bureau Statistics in 2018, the largest OUR is still dominated by the provinces situated in Java island, with the percentage rate of unemployment ranging from $3.2 \%$ to $8.5 \%$. In the second place, Sumatera island has shown a relatively high OUR which spans from $3.6 \%$ to $7.1 \%$. Whilst, Borneo island has taken third place with OUR ranges from $3.9 \%$ to $6.5 \%$ respectively. Given the situation at the national level, it has been recorded that OUR in 2018 is around $5.34 \%$ on average. These statistics imply that there is a pretty huge gap between the OUR in one region and another, in which the second largest OUR is dominated by the provinces of Sumatera island.

The high variation of OUR on large islands in Indonesia (e.g., Java, Sumatera, Borneo, Sulawesi, Nusa Tenggara, and Papua) shows that the programs and efforts of the central government to suppress the OUR in these regions have not been implemented successfully and equitably. The prior studies showed that there could be many factors that might influence the variation of OUR. Among them, the most adopted indicators in the empirical research are the economic growth (EG), inflation (INF), and regional minimum wages (RMW) (Putro \& Setiawan, 2013; Said, 2017; Rohman et al., 2016; Albarqi 2016; Valentine, 2018; Wijayanti, 2014; Qomariyah, 2013; Prayogo, 2016; and Ramiayu, 2016). Therefore, we finally decide to adopt the previous research by combining some macroeconomic factors as the independent variables, where we conjecture that OUR is the function of EG, INF, and RMW.

Empirically, the burgeoning number of previous empirical evidence have documented inconsistent and inconclusive relationship between the variable of interest (e.g., EG, INF, RMW, and OUR). Take, for instance, in the investigation of the relationship between the economic growth (EG) and open unemployment rate (OUR), the studies of Putro and Setiawan (2013), Said, (2017), and Rohman, Balafif \& Wahyuni (2016) found that there is a negative and significant relationship between EG and OUR in several cities such as Malang, Makasar, and East Java province. On the contrary, the study of Albarqi (2016) utilized the gross domestic product (GDP) as a proxy for $E G$ in the East Java province. As a result, they found a positive and significant relationship between GDP and OUR. However, research conducted by Valentine (2018) in Yogyakarta showed that EG and OUR are insignificantly associated.

110 | Putra, R., Sukiyono, K., Purmini. Economic Growth, Inflation, and ... 
Furthermore, in the context of the relationship between the inflation variable (INF) and the open unemployment rate (OUR), the research of Wijayanti's (2014) found that INF had shown a negative and significant effect on OUR in the province of Bali. On the other hand, Rohman et al., (2016) found a significant and positive relationship between INF and OUR in East Java province. The study of Valentine (2018) also found a positive and significant relationship between INF and OUR in Yogyakarta. Interestingly, although using the same setting study, the study of Qomariyah (2013) in East Java province found an inconclusive result, where she documented that INF and OUR are insignificantly associated.

Concerning the relationship between the regional minimum wage (RMW) and the open unemployment rate (OUR), the studies of Rohman et al., (2016), Said, (2017), and Valentine, (2018) found that there was a negative and significant relationship between RMW and OUR in East Java province, Makassar, and Yogyakarta city. However, the study of Prayogo, (2016) contrastingly found a positive and significant relationship between the RMW and OUR in the province of Central Java. In addition to the literature which showed the conflicting results (positive vs. negative) between RMW and OUR, the study of Ramiayu, (2016) used the data from East Java province and she found that RMW and OUR showed inconclusive (insignificant) relationship. Given this circumstance, it is necessary important for the researcher to provide a newly investigated setting of study apart from the Java setting.

As the response to the call of the previous studies, we aim at responding to the scientific findings in prior literature that have been providing inconsistent and inconclusive empirical evidence. Thus, our research is expected to provide two contributions; (1) to fill in the research gap in several works of literature that is still inconclusive and inconsistent. In this regard, we offer a different set of studies by empirically investigating a panel dataset extracted from Sumatera island. (2) to provide a practical implication in the form of policy recommendations to the regulators in each province situated in Sumatera island.

The remaining of this paper is divided into several sections and subsections. Section two elaborates on the research method. Section three provides the result and discussion of the obtained empirical evidence. Section four compiles the conclusion of the study and offers the practical and implication either for policymakers or the private sector.

\section{RESEARCH METHODS}

\section{Method of Collecting Data}

We extract the data concerning the information on economic growth (EG), inflation (INF), regional minimum wage (RMA), and the open unemployment rate (OUR) from the annual report published the National Beauro of Statistics. We deliberately extract these data for ten provinces in Sumatera island (e.g., Aceh, North Sumatera, West Sumatera, Riau, Jambi, South Sumatera, Bengkulu, Lampung, Bangka Belitung island, and Riau island). The reason to pick these ten provinces is given the position of Sumatera island as the second big island with the highest open unemployment rate after Java island. Meanwhile, we deliberately use the annual data 
to allow us better in estimating the annual variation of OUR. Thus, we utilize pretty long time-series observation which spans from 2006 and 2018 (13 years). We decide to limit the starting point of our data extraction in 2006 due to the inability to extract the earlier data. As explained by the national central bureau of statistics in their reports, the data compilation of provinces in Sumatera island was incomplete due to the extensive expansion of new autonomous regions in Sumatra. Thus, we were unable to collect sufficient data and finally decide to limit the data from 2006 to 2018.

\section{Data Analysis Method}

\section{Empirical Model}

Given the nature of cross-sectional (ten provinces) and time-series data combination (13 years), we, therefore, decide to run a panel data analysis with the total observation stands at 130 year-observation. To empirically test the variation of OUR as the function of EG, INF, and RMW, we thus express the empirical notion into a statistical model as follows.

$$
\text { OUR_(i,t)= } \beta 0+\llbracket \beta 1 E G \rrbracket \_(i, t)+\llbracket \beta 2 I N F \rrbracket \_(i, t)+\llbracket \beta 3 R M W \rrbracket \_(i, t)+\varepsilon
$$

The subscript i stands as province i, while subscript t means the year. More in detail, we have one dependent variable and three independent variables. OURi,t is the dependent variable, which denotes the annual open unemployment rate in the provinces of Sumatera island. Furthermore, our first independent variable is EGi,t, which means the percentage of the annual economic growth. The second independent variable is INFi,t, which stands for the percentage of the yearly inflation rate. The last independent variable is RMWi,t which means the regional minimum wage in Sumatera island, where the unit data of this variable is provided in the Indonesian currency (Rp). To deal with the linearity issue, we need to transform the RMW data which is initially extracted in currency type into Logarithm Natural of RMW. Thus, the notion of the third independent variable is modified from RMWi,t to Ln_RMWi,t. The new statistical notation is available as follows.

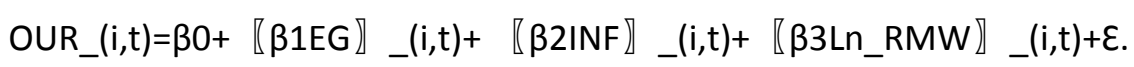

Before performing panel data regression, we need to deal with the data consistency (i.e., classical assumption; dealing with the issues of multicollinearity, autocorrelation, heteroscedasticity, and normality test) and model selection (common effect model vs. fixed effect, vs. random effect model) to guarantee that the results of our estimation provide us with the most efficient regression estimation. With regard to the classical assumption test, we do not perform the complete test but only deal with the multicollinearity and heteroscedasticity test. Moreover, to deal with model selection, we compare three models in panel data analysis and justify the model selection based on the result of the Chow test (CEM vs. FEM) and Hausman test (FEM vs. REM). As a result of model selection using the Chow and Hausman test, our empirical result finally

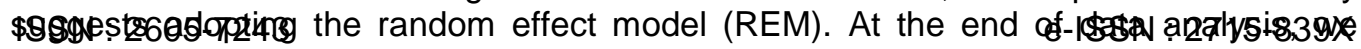
draw our conclusion based on the justification on the $\mathrm{F}$ test (simultaneous test), t-test

(partial test), and coefficient determination test of the obtained panel data regression output.

112 | Putra, R., Sukiyono, K., Purmini. Economic Growth, Inflation, and ... 


\section{RESULTS AND DISCUSSION}

\section{Descriptive Statistics}

Our analysis is started by providing the descriptive statistics of each variable of interest. Table 1 presents.

Table 1. Descriptive statistics

\begin{tabular}{lllllllll}
\hline Variable & Count & mean & sd & p25 & p50 & p75 & min & max \\
\hline OUR & 130 & 6.437 & 2.10 & 4.09 & 6.225 & 8.01 & 2.06 & 12.24 \\
EG & 130 & 4.97 & 2.04 & 4.42 & 5.235 & 6.02 & -5.58 & 7.86 \\
INF & 130 & 5.67 & 3.29 & 03.02 & 2.27 & 8 & 0.08 & 18.04 \\
Ln_RMW & 130 & 14.02 & 0.47 & 13.61 & 13.99. & 14.40 & 13.13 & 16.01 \\
\hline
\end{tabular}

Source: Own elaboration, 2020.

Note : p25=25/100.N, p50=50/100.N, p75=75/100.N.

Table 1 elaborates on the descriptive statistics of the dependent (OUR) and independent variables (i.e., EG, INF, and Ln_RMW). As can be seen in Table 1, we show the information of mean, standard deviation (sd), the minimum value, percentile 25th, 50th, 75th, and the maximum value. Regarding the dependent variable, we report that the mean value of the open unemployment rate in ten provinces of Sumatera island is 6.437 on average, with the lowest OUR is recorded as 2.06 and the maximum OUR stands at 12.24. Moreover, in respect of the independent variables, we document that the mean value of economic growth (EG) is 4.97 on average, with the minimum and maximum values stand at -5.58 and 7.86 respectively. The information on inflation (INF) shows a mean value of 5.67, while the minimum and the maximum value are 0.08 and 18.04 consecutively. The last variable is the Logarithm Natural of the regional minimum wage (RMW). The mean value of Ln_RMW is 14.02 on average, while the minimum value is 13.13 and the maximum value is 16.01. Apart from the descriptive information on the overall dependent and dependent variable, we also provide the average value of OUR for each province during the period of observation from, 2006 to 2018 in Figure 1.

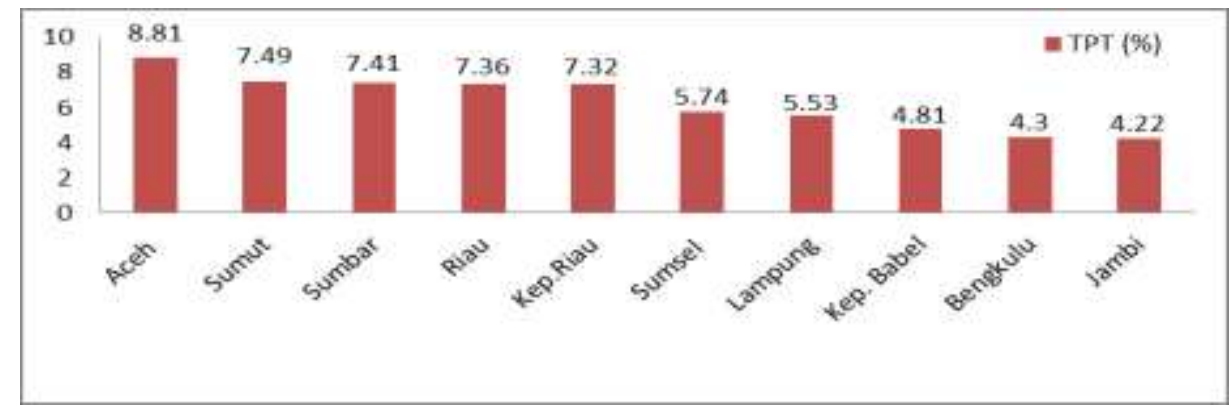

Figure 1. The mean of OUR in ten provinces of Sumatera island from 2006 to 2018

Figure 1 illustrates the mean of the open unemployment rate (OUR) for each province (Aceh, North Sumatera, West Sumatera, Riau, Riau island, South Sumatera, Lampung, Bangka Belitung island, Bengkulu, and Jambi) situated in Sumatera island from 2006 to 2018. As can be seen in Figure 1, the relatively high average value of

Journal of Agri Socio Economics and Business, Vol. 03 No. 2 page: 109 - 122|113 
OUR in each province is caused by the high rate of OUR from the last 13 years. Mostly, the unemployment rate is dominated by those who were graduated from middle and high school. It is pretty difficult for the man in charge (i.e., regent, and governor) to deal with the unemployment rate in Sumatera island. This problem is also triggered by the relatively low skill and competence of human resources unable to find a proper job. More in detail, the data from the last 13 years shows that Aceh is reported with the highest OUR value as 8.81 percent on average. This number is followed by North Sumatera (7.49 percent) and West Sumatera (7.41 percent) in the second and third places respectively. Meanwhile, the province with the lowest OUR rate since the last 13 years is Jambi with the OUR value stands at 4.22 on average. This number is followed by Bengkulu and Bangka Belitung island as the second (4.3 percent) and third (4.81 percent) lowest OUR rate since the last 13 years.

\section{Correlation Analysis and Heteroscedasticity Detection}

To deal with multicollinearity test, we perform a Pearson correlation analysis and provide the correlation analysis output as follows. Table 2 illustrates.

Table 2. Correlation matrix.

\begin{tabular}{lllll}
\hline Variables & OUR & EG & INF & Ln_RMW \\
\hline OUR & 1 & & & \\
EG & $-0.295 * * *$ & 1 & & \\
& $(0.001)$ & & & \\
INF & 0,0875 & 0.094 & 1 & \\
& $(0.153)$ & $(0.289)$ & & \\
Ln_RMW & $-0.323 * * *$ & $-0.251^{* *}$ & $-0.373 * * *$ & 1 \\
& $(0.000)$ & $(0.004)$ & $(0.000)$ & \\
\hline
\end{tabular}

${ }^{\star \star *} p<0.01,{ }^{* \star} p<0.05,{ }^{*} p<0.1$ indicate statistical significance at the 1 percent, 5 percent and 10 percent level respectively (two-tailed).

Table 2 displays the inter-correlation analysis output among the employed variables. As can be seen, economic growth $(E G)$ as the first independent variable has shown a negative $(r=-0.295)$ and significant $(p<0.01)$ correlation with OUR as the dependent variable. However, inflation (INF) does not indicate any significant correlation with OUR. The last independent variable is the Logarithm Natural of the regional minimum wage (Ln_RMW). This independent variable reports a negative ($0.323)$ and significant $(p<0.01)$ correlation with the open unemployment rate (OUR). Regarding the detection of multicollinearity issues, our correlation matrix indicates that none of the inter-correlation values show a correlation higher than 0.8 , suggesting that our dataset has experienced no multicollinearity problem. Moreover, the detection of the heteroscedasticity is performed through the Park and Glejser tests. As can be seen

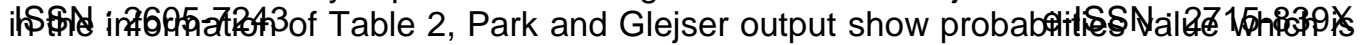
bigger than 0.05 . Thus, it can be inferred that the regression model has experienced no heteroscedasticity issue. Table 3 displays.

Table 3. Park and Glejser test output

\section{Variable Coefficient Std. Error t-Statistic Prob.}

114 | Putra, R., Sukiyono, K., Purmini. Economic Growth, Inflation, and ... 


\begin{tabular}{lllll} 
C & 3.2725 & 3.0128 & 1.0861 & 0.2795 \\
EG & 0.0045 & 0.0479 & 0.0953 & 0.9242 \\
INF & 0.0094 & 0.0064 & 1.4699 & 0.1441 \\
LN_RMW & -0.1294 & 0.2098 & -0.6169 & 0.5384 \\
\hline
\end{tabular}

Source: Own elaboration, 2020.

\section{Main Analysis}

Recall to the suggested model selection, our previous analysis on Chow and Hausman test recommends running the panel data analysis model with a random effect model (REM). Thus, we run the analysis and present the empirical results as can be observed in Table 4 as follows.

Table 4. Regression analysis with a random effect model

\begin{tabular}{|c|c|c|c|c|}
\hline \multirow{2}{*}{$\begin{array}{l}\text { Variable } \\
\mathrm{C}\end{array}$} & \multicolumn{2}{|c|}{ CoefficientStd. Error } & \multirow{2}{*}{$\begin{array}{l}\text { t-Statistic } \\
10.5573\end{array}$} & \multirow{2}{*}{$\begin{array}{l}\text { Prob. } \\
0.0000\end{array}$} \\
\hline & 37.8927 & 3.5892 & & \\
\hline $\mathrm{EG}$ & -0.2006 & 0.0778 & -2.5769 & 0.0111 \\
\hline INF & -0.0011 & 0.0077 & -0.1453 & 0.8846 \\
\hline$\underline{\mathrm{LN} \_R M W}$ & -2.1719 & 0.2476 & -8.7698 & 0.0000 \\
\hline \multicolumn{5}{|l|}{ Random Effects (Cross) } \\
\hline $\mathrm{ACEH}-\mathrm{C}$ & 1.8415 & & & \\
\hline NORTH_SUMATERA-C & 1.1329 & & & \\
\hline WEST_SUMATERA-C & 0.9869 & & & \\
\hline $\mathrm{RIAU-C}$ & 0.9939 & & & \\
\hline $\mathrm{JAMBI}-\mathrm{C}$ & -1.5185 & & & \\
\hline SOUTH_SUMATERA-C & -0.1187 & & & \\
\hline BENGKULU-C & -2.2669 & & & \\
\hline LAMPUNG-C & -0.6880 & & & \\
\hline BANGKA_BELITUNG_ISLAND—C & -1.4549 & & & \\
\hline RIAU_ISLAND—C & 1.0919 & & & \\
\hline R-squared & 0.3781 & & & \\
\hline Adjusted R-squared & 0.3633 & & & \\
\hline F-statistic & 25.537 & & & \\
\hline Prob(F-statistic) & 0.0000 & & & \\
\hline
\end{tabular}

Source: Own elaboration, 2020.

When we transform the above statistical outputs into a mathematical model, the information can be derived as follows;

$$
\begin{gathered}
\text { OUR }_{i, t}=\beta 0+\beta 1 \mathrm{EG}_{\mathrm{i}, \mathrm{t}}+\beta 2 \mathrm{INF}_{\mathrm{i}, \mathrm{t}}+\beta 3 \mathrm{Ln}_{-} \mathrm{RMW}_{\mathrm{i}, \mathrm{t}}+\varepsilon \\
\mathrm{OUR}_{\mathrm{i}, \mathrm{t}}=37.8927-0.2006 \mathrm{EG}_{\mathrm{i}, \mathrm{t}}-0.0011 \mathrm{INF}_{\mathrm{i}, \mathrm{t}}-2.1719 \mathrm{Ln}_{-} \mathrm{RMW}_{\mathrm{i}, \mathrm{t}}
\end{gathered}
$$

Std. Error $=(3.589217)(0.077861) \quad(0.007700) \quad(0.247663)$ 
Table 4 illustrates the main results of the panel data estimation output of the proposed empirical model. The statistical model itself was run by employing panel data regression with a random effect model (REM). As previously conjectured, our notion is to investigate if OUR is the function of EG, INF, and Ln_RMW. As informed by Table 4, we can infer that the partial test of the first independent variable (EG) has shown a negative $(-0.2006)$ and significant $(p<0.01)$ relationship with the open unemployment rate (OUR). This means that the increase in economic growth (EG) as one percent is negatively associated with OUR as 0.20 percent. Moreover, the direct test on the second independent variable shows that inflation (INF) has negatively $(-0.0011)$ but insignificantly $(p<0.05)$ associated with the open unemployment rate (OUR). The results suggest that even though the coefficient beta of INF is negative, but the obtained empirical evidence shows that the effect of this coefficient is not different from zero, which indirectly imply inconclusive result on the relationship between INF and OUR. The last test is conducted using the Logarithm Natural of the regional minimum wage (Ln_RMW). The output shows that Ln_RMW is negatively and significantly associated with OUR. More in detail, this value means that if there is an increase as one percent on the regional minimum wage, there should be a decrease as 2.17 percent. In addition to this, we also provide the statistical model for each province in Sumatera island, and the model is available as follows.

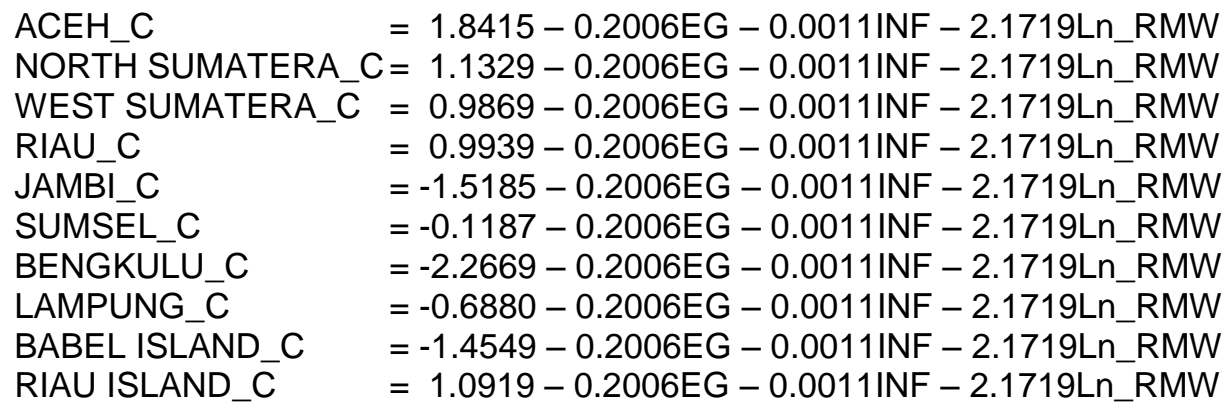

\section{$(0.077861)(0.007700) \quad(0.247663)$}

As can be inferred from the above different simulations at the province levels, we report that out of ten provinces, there are five provinces with positive constant $(\beta 0)$ values (i.e., Aceh, North Sumatera, West Sumatera, Riau, and Riau Island). While, on the other hand, we also document that the remaining five provinces indicate negative constant $(\beta 0)$ values (i.e., Jambi, South Sumatera, Bengkulu, Lampung, and Bangka Belitung island). When the constant values of a province are positive, it means that in

116 | Putra, R., Sukiyono, K., Purmini. Economic Growth, Inflation, and ... 
the ceteris paribus situation, the present value of the open unemployment rate is positive or relatively higher, thus the negative effects of the three independent variables (i.e., EG, INF, and Ln_RMW) can help to reduce the open unemployment rate, and vice versa.

More in detail, we also meticulously identify the obtained empirical output through the lens of simultaneous test and model fitness. Referring back to the $\mathrm{F}$ test value in Table 3 , it is obvious that the obtained $F$ value is statistically significant $(p<$ 0.01 ) and the $F$ value (25.537) is much bigger than the F table (4). Given that, we may draw our explanation that at least one of the three independent variables used in the proposed statistical model is able to explain the potential variation of the open unemployment rate (OUR). As a matter of fact, out of three, we have two independent variables ( $E G$ and $L n \_R M W$ ) that statistically associated with OUR. Meanwhile, INF provides us with inconclusive empirical output. In addition to this, the obtained $R$ square value $\left(R^{2}\right)$ indicates that 37.81 percent of the variation in the open unemployment rate (OUR) can be explained by the three independent variables (EG, INF, and Ln_RMW). While the other 62.19 percent of OUR variation is explained by the omitted factor that is not identified in the proposed empirical model.

\section{Discussion}

Our study provides the empirical evidence on the relationship between three independent variables extracted from macroeconomics information (i.e., economic growth (EG), inflation (INF), and regional minimum wage (RMW)) and the open unemployment rate (OUR) in Sumatera island, Indonesia. In general, using the data taken from ten provinces located in Sumatera island for the period of observation ranges from 2006 to 2018 (130 province-year observations), our results agreed quite well with the a priori theory and prior studies.

In respect of the relationship between Economic Growth (EG) and the open unemployment rate (OUR), Our empirical test reports that there is a negative relationship between EG and OUR among provinces in Sumatera island. In this regard, we report that the obtained evidence is in line with the Okun's Law, which states that economic growth and open unemployment rate are linearly related. The logic is, the unemployment rate is more likely to be decreasing when the economic growth gets higher (negative relationship). When the economic growth steadily increases, it triggers the increase in good and service productions, and the production processes need more production factors such as laborers. Our results are consistent with the findings of Ramiayu, (2016) who previously has reported a negative relationship between EG and OUR in East Java. However, our result takes a confronted result in comparison with the study of Rohman et al., (2006) who found a positive relationship between EG and OUR in East Java. As can be seen from the visual comparison data of the last five years of economic growth and OUR in Sumatera island, it can be reported that the national OUR rate is decreasing (from 5.84 in 2014 to 4.98 in 2018), whilst the EG in Sumatera island incline to be more stable (from 4.93 in 2014 to 4.67 percent in 2018 on average). However, if we take a look at the graph more carefully, the EG rate in 2015 touched the lowest point at 4.41 percent while it raised to 4.67 percent in 2018 . Figure 1 illustrates. 


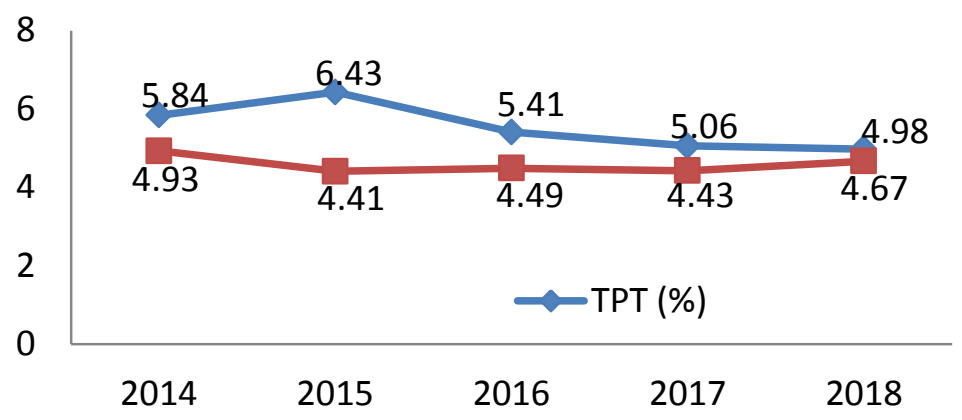

Figure 2. Economic growth (EG) and the open unemployment rate (OUR) in Sumatera island from 2014 to 2018

Moreover, regarding the relationship between inflation (INF) and the open unemployment rate (OUR), our estimation shows that inflation (INF) is not statistically associated with the open unemployment rate (OUR) of provinces in Sumatera island. Our result is different from the study of Etry, (2014) and Wijayanti, (2014) who found a negative and significant relationship between INF and OUR. While, our study is consistent with the findings of Qomariyah, (2013) who reported that there is no clear relationship between inflation and unemployment rate in East Java. Theoretically, the insignificant relationship between these two (INF and OUR) variables is given the external factor that may drive the variation of OUR. Take, for example, Qomariyah, (2013) noted that it is not the inflation of goods and oil that was triggered by the higher demand as explained by the Philip curved, which finally lead to an insignificant relationship between INF and OUR. However, as documented by the study of Maximova, (2015) this propensity only stands for the short-run, not for the long-run because inflation is required to maintain market stability.

We also highlight the relationship between the regional minimum wage (RMW) and the open unemployment rate (OUR). The obtained empirical evidence documents that the regional minimum wage is negatively and significantly related to the variation of the open unemployment rate in Sumatera island. This suggests that when there is an increase in the wage, it should be negatively related to the decrease in unemployment. This is in line with the a priori theory. Kaufman and Hotckiss, (1999) also noted that the labor need to choose the minimum level of the wage they can get and at the same time should be affordable for the companies. When a person does not receive the minimum level of wage as agreed by the government, companies, and labor union as the minimum wage, then this person could be considered as potential unemployed labor as he cannot manage to deal with the agreed wage. Moreover, if in an area the minimum wage is too low than its regional minimum wage, it should go without saying that there is an oversupply of labor that makes them need to receive

118 | Putra, R., Sukiyono, K., Purmini. Economic Growth, Inflation, and ... 
The low wage even though in fact, the obtained wage is far from enough. Therefore, as explained by Keynes, a labor union is needed to protect the labor from exploitation.

Concerning the prior study, our finding on the relationship between RMW and OUR is similar to the findings of Rohman et al., (2016), Said, (2017), and Valentine, (2018) who found that minimum wage is negatively associated with the unemployment rate. When the minimum wage in a company is too low than the agreed regional minimum standard, it should not attract the talent to work on that company. In the case where the education level of the talent is higher, and at the same time the offered salary is low, the talent may think twice to accept the job. In this context, most of the talent prefers the take-home pay that adequately appreciates their educational background. Thus, the low minimum wage may lead to higher unemployment.

\section{CONCLUSIONS AND POLICY IMPLICATIONS}

Recall back to the obtained empirical evidence using panel data analysis on ten provinces in Sumatera island from 2006 to 2018, we could conclude that the open unemployment rate is the function of economic growth, inflation, and regional minimum wage. These three macroeconomic factors are negatively associated with the open unemployment rate. However, only inflation shows the inconclusive result, in which inflation shows a negative association with the unemployment rate but statistically insignificant.

In a more general view, we also conclude that the open unemployment rate in Sumatera island from the last twelve years is still relatively high. The main cause of this phenomenon could be explained by the improper absorption of labor in the market. The most interesting case can be seen from the high number of well-educated unemployed laborers or talents. Therefore, apart from the government's focus on the high intense labor prosperity in many big cities in Java and Sumatera, the government has to take into account the problems for the well-educated labor that is available in the job market. As the number of well-educated talents is growing, and mostly these talents are the millennials, the government needs to facilitate them with better support and incentive. Take, for instance, the government needs to map this talent based on their age category and skill profiles. If these talents are mostly dominated by the millennials generation who have been exposed by ITC (Information, Technology, and Communication) skills, the government may provide some relevant policy and incentive to supports these millennials to start their business (start-up model). However, if the demographical profile of the talents is millennials without proper ICT skills, the government may facilitate these talents to acquire new ICT skills to help them better provide themselves with a set of skills as required by the industry.

\section{REFERENCES}

Ali. F, 2015. BPS. Tingkat pengangguran terbuka meningat dari tahun sebelumnya. Accesed from https://money.kompas.com/read/2015/11/05/171744726/ BPS.Tingkat.Pengangguran.Terbuka.Meningkat.dari.Tahun.Sebelumnya [12/02/20] 
Alisa, Maximova. 2015. The Relationship between Inflation and Unemployment: $A$ Theoretical Discussion about the Philips Curve: Southeast University. American Research Institute for Policy Development. 3(2) : 89-97. Doi: 10.15640/jibe.v3n2a7

Aqil. 2014. Determinants Of Unemployment In Pakistan. : Defence Authority Degree College, Karachi, Pakistan. IJPSS. 4(4) : 1-7. Retrieved from http://www.indianjournals.com/ijor.aspx?target=ijor:ijpss\&volume $=4 \&$ issue $=4$ \&article $=054$

Astari, Mayra. 2019. Hukum Okun: Pertumbuhan Ekonomi dan Tingkat Pengangguran di Indonesia: Universitas Lampung. Retrieved from http://repository.lppm unila.ac.id/16233/1/4.-Hukum-OKUN-Pertumbuhan-Ekonomi-Dan-TingkatPengangguran-Di-Indonesia.pdf

Case and Fair. 2006. Prinsip- prisip ekonomi. Jakarta: Erlangga. Chowdhury. 2014. Determinants of Unemployment in Bangladesh: A Case Study: Jatiya Kabi Kazi Nazrul Islam University Trishal, Mymensingh, Bangladesh. IISTE. 4(3): 1-5. Retrieved from https://papers.ssrn.com/sol3 /papers.cfm?abstract_id $=2402908$

Cita Ekonomika Jurnal Ekonomi. 2014. Analisis Pengaruh Inflasi Dan Pertumbuhan Ekonomi Terhadap Pengangguran Di Kota Ambon: Universitas Patimura. 8(1) : 58-63. Retrieved from https://ejournal.unpatti .ac.id/ppr_paperinfo Ink.php?id=655

David, Albarki, 2016. Kajian empiris tentang tingkat TPT di Jawa Timur. 4(2) : 1-14. Retrieved from https://jimfeb.ub.ac.id/index.php/jimfeb/article/view/2655/2402 Dwi, Aprilia Putri. 2014. Analisis Beberapa Faktor yang Mempengaruhi Tingkat Pengangguran Terbuka di Jawa Timur Tahun 2003-2014: Universitas Negeri Surabaya (UNS).4(3) : 1-8. Retrieved from https://jurnalmahasiswa.unesa.ac.id/index.php/jupe/article/view/1661 $6 / 15092$

Gujarati N , Damodar. 2010. Dasar- dasar Ekonometrika. Jakarta : Salemba empat.

I, Komang Agus Adi Putra. 2018. Analisis Pengaruh Tingkat Pengangguran Terbuka, Kesempatan Kerja, Dan Tingkat Pendidikan Terhadap Tingkat Kemiskinan Pada Kabupaten/Kota Di Provinsi Bali: Universitas Udayana.

E-Jurnal Ekonomi Pembangunan. 7(3) : 416-444. Retrieved from https://ojs.unud.ac.id/index.php/eep/article/view/37696/23655

Isnayanti, Arnah Ritonga. 2017. Analisis Faktor-Faktor Yang Mempengaruhi Tingkat Pengangguran Di Provinsi Sumatera Utara Tahun 1978-2014 Dengan Metode Ordinary Least Square: Universitas Negeri Medan. 3(2) :1-18. DOI: https://doi.org/10.24114/jmk.v3i2.8809

Kaufman, Bruce E., and Julie L. Hotchkiss. 1999. Economic Labor Markets. USA: Georgia State University

Kristyana. 2011. Pengaruh Upah Minimum Kabupaten/ Kota (Umk), Pertumbuhan Ekonomi Dan Inflasi Terhadap Pengangguran Terbuka Di Jawa Tengah Tahun 2004-2009: Universitas Negeri Semarang. Retrieved from https://lib.unnes.ac.id/10756/1/9026.pdf

Mankiw, Gregory. 2007. Prinsiple of economics. Fitria Liza (Penerjemah) dan Imam Nurmawan (Editor). Makro Ekonomi. Jakarta: Erlangga.

120 | Putra, R., Sukiyono, K., Purmini. Economic Growth, Inflation, and ... 
Pamela. 2014. Linking Unemployment To Inflation And Economic Growth: Toward A Better Understanding Of Unemployment In The Philippines : Iligan Institute Of Technology Of Iligan City, Philippines. Asian Journal of Economic Modelling. 2(4) : 156-158. Retrieved from

https://www.researchgate.net/profile/Pamela Resurreccion/publication/304163 05_Linking_unemployment_to_inflation_and_economic_growth_Toward_a_bet ter_understanding_of_unemployment_in_the_Philippines/links/5768d2c808aef 9

750b0fa52e/Linking-unemployment-to-inflation-and-economic-growth-Towarda-better-understanding-of-unemployment-in-the-Philippines.pdf

Prastiwi, Dian. 2019. Analisis pengaruh jumlah penduduk, pendidikan, upah minimum, dan PDRB terhadap TPT di Provinsi Jawa Tengah. Diponegoro Journal of Economics. 1(1) : 1-11. Retrieved from https://ejournal2.undip.ac.id/index.php/dje/article/view/4058/2403

Prawira, Syurifto. 2018. Pengaruh Pertumbuhan Ekonomi, Upah Minimum Provinsi, Dan Tingkat Pendidikan Terhadap Pengangguran Terbuka Di Indonesia: Universitas Negeri Padang (UNP). Jurnal Ecogen. 1(1) : 162-168. Retrieved from http://ejournal.unp.ac.id/students/index.php/pek/article/view/4735/2647

Qomariyah. 2013. Pengaruh tingkat inflasi dan pertumbuhan ekonomi terhadap tingkat pengangguran di Jawa Timur. : Universitas negeri Surabaya. Jurnal $\begin{array}{llll}\text { Pendidikan } & \text { Ekonomi. 1(3):1-8. Retrieved from }\end{array}$ https://jurnalmahasiswa.unesa.ac.id/index.php/jupe/article/view/3647/6240

Rohman, dkk, 2016. Pengaruh PDRB, inflasi dan UMR terhadap TPT di jawa Timur tahun 1994-2013. 2(1) : 1-11. http://fe.ubhara.ac.id/ojs/index.php/ global/article/view/242/227

Rosyda, Nur Fauziyah. 2018. Faktor-Faktor Yang Mempengaruhi Tingkat Pengangguran Terbuka Di Pulau Jawa Tahun 2010-2015: Universitas Islam Indonesia. Retrieved from https://dspace.uii.ac.id/bitstream/handle /123456789/5477/FIX\%20SKRIPSI\%20DI\%20CD\%20\%28rosyda\%20nur\%20f auziyah\%29.pdf? sequence $=1$ \&isAllowe $\mathrm{d}=\mathrm{y}$

Said, Risvi N, 2017. Pegaruh upah minimum regional, investasi dan pertumbuhan ekonomi terhadap pengangguran di Kota Makasar. Universitas Uin Alauddin Makasar. Retrieved from http://repositori.uinalauddin.ac.id/7804/1/NURHIKMAH\%20RISVI\%20SAID.pdf

Samuelson, P. A. dan Nordhaus, W. D. 2004. Ilmu Makro Ekonomi : Edisi Tujuh Belas. PT Media Global Edukasi, Jakarta.

Shinta, Setya Ningrum. 2017. Analisis Pengaruh Tingkat Pengangguran Terbuka, Indeks Pembangunan Manusia, Dan Upah Minimum Terhadap Jumlah Penduduk Miskin Di Indonesia Tahun 2011-2015. JEP. 15(2) : 185-192. https://doi.org/10.22219/jep.v15i2.5364

Sidania, Jefti. 2017. Determinants Of Open Unemployment Rate In Banten Province Period 2008-2013: Universitas Jember (UNEJ). DOI: https://doi.org/10.19184/ejeba.v4i2.5792 
Sukirno, Sadono. 2012. Makroekonomi Teori Pengantar. Jakarta: PT RajaGrafindo Persada.

Sukirno, Sadono. 2007. Ekonomi Pembangunan: Proses, Masalah, dan Dasar Kebijakan. Kencana, Jakarta.

Sumartini. 2017. Indonesian Economic Growth Rate: Inflation and Unemployment Rate Analysis: 1Universitas Pendidikan

Setiabudhi 229 street Bandung, Indonesia. Retrieved from https://www.researchgate.net/publication/325609363

Thayaparan, A. 2015. Impact of Inflation and Economic Growth on Unemployment in Sri Lanka: A Study of Time Series Analysis: Vavuniya Campus of the University of Jaffna. Global Journal of Management and Business. 14(5-B. Retrieved from http://www.journalofbusiness.org/index.php/GJMBR/ar ticle/view/1346

Todaro, Michael.P. 2000. Pembangunan Ekonomi. Jakarta: Bumi Aksara.

Trianggono, Budi Hartanto. 2017. Analisis Pengaruh Jumlah Penduduk, Pendidikan, Upah Minimum Dan Produk Domestik Regional Bruto (Pdrb) Terhadap Jumlah Pengangguran Di Kabupaten Dan Kotaprovinsi Jawa Timur Tahun 2010-2014: Universitas Airlangga. JIET. 2(1):21-30. Retrieved from http://dx.doi.org/10.20473/jiet.v2i1.5502

Umar, Husein. 1999. Metodologi Penelitian. Jakarta: Gramedia.

Umair, M .2013. Impact of GDP and Inflation on Unemployment Rate: $A$ Study of Pakistan Economy in 2000-2010: University Peshawar Pakistan.International Review of Management and Business Research. 2(2) : 1-13. Retrieved from http://citeseerx.ist.psu.edu/viewdoc/download?doi=10.1.1.680.6180\&rep=rep1\& type $=$ pdf

Valentin, R,S. 2018. Pengaruh Inflasi, UMR, jumlah pariwisata dan PDRB terhadap pengangguran di DIY: Universitas Islam Indonesia, Yogyakarta. Retrieved fromhttps://dspace.uii.ac.id/bitstream/handle/123456789/6263/jurnal\%20shella. pdf?sequence $=2$ \&isAllowed $=y$

Winarno, wing wahyu. 2009. Analisis ekonometrika dan statistik dengan Eviews.

Yogyakarta: STIM YKPN.

Widarjono, Agus. 2009. Ekonometrika Pengantar dan Aplikasinya. Ekonisia,Yogyakarta

Yelwa. 2015. Analysis Of The Relationship Between Inflation, Unemployment, And Economic Growth In Nigeria: 1987-2012: University of Abuja- Gwagwalada, Nigeria. RedFame. 2(3): 1-8. DOI:10.11114/aef.v2i3.943

122 | Putra, R., Sukiyono, K., Purmini. Economic Growth, Inflation, and ... 